\title{
Paracentesis-induced circulatory dysfunction: are there albumin alternatives?
}

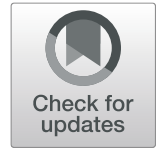

\author{
Ayman Alsebaey ${ }^{*}$ (D), Eman Rewisha and Imam Waked
}

\begin{abstract}
Background: Ascites is one of the main complications of advanced liver cirrhosis. It is defined as a pathological accumulation if free fluid in the peritoneal cavity.

Main body of the abstract: Ascites is a sign of decompensation in patients with liver cirrhosis and is associated with decreased survival. Ascites is associated with bad cosmetic figure and poor quality of life. Ascites is a predisposing factor for developing hydrothorax, hernias, diastolic dysfunction, spontaneous bacterial peritonitis, and renal impairment especially hepatorenal syndrome. The main treatment is salt restriction and diuretics. By the time the patient become non-responder and develop tense ascites, abdominal large volume paracentesis is the treatment of choice. Its advantages are rapid, cheap, and 1 day hospitalization. The main drawback is the development of paracentesis-induced circulatory dysfunction (PICD) if no volume expanding drugs are used. PICD is associated with dilutional hyponatremia, renal impairment, so it is considered the silent killer. Albumin infusion is the standard preventive measure but since costly to other alternatives such as colloids, vasoconstrictors or lowering the standard doses of the albumin was studied and is promising.
\end{abstract}

Conclusions: This review summarized the effectiveness of other alternative drugs.

Keywords: Ascites, Large volume paracentesis, Albumin, Paracentesis-induced circulatory dysfunction

\section{Background}

The ancient Egyptians identified liver disease and linked the presence of ascites to disease of the liver as early as the time of the Ebers papyrus, where paragraph 865 refers to a swelling of the abdomen with the "water going up and down" or freely moving, which is a very accurate description of ascites and how to detect it clinically $[1,2]$. The recommended treatment was to pierce the abdomen with what is called a "hmmm" (supposedly a knife or sharp instrument) to drain the fluid, as in performing paracentesis. they also noted that "hardness of the liver" was a risk factor for ascites formation [3].

\footnotetext{
* Correspondence: aymanalsebaey@liver.menofia.edu.eg; https://orcid. org/0000-0003-3781-2312

Department of Hepatology and Gastroenterology, National Liver Institute, Menoufia University, Shebeen El-Koom 32511, Egypt
}

Hippocrates was the first one who use the term "ascites" which is derived from the Greek word (áoxo ; askos), i.e., a leather bag that was used to carry fluids [4].

Half of the cirrhosis patients develop ascites within 10 years. After the occurrence of ascites, the survival decreases dramatically where $50 \%$ of the patients survive for 2-5 years. The 1 - and 5-year survival without transplantation is 85 and $55 \%$, respectively [5].

Liver cirrhosis and portal hypertension account for $75 \%$ of all ascites cases [6]. Portal hypertension, arterial vasodilatation, neurohumoral activation, and renal dysfunction are the proposed pathogenesis factors [7]. Clinically, ascites can be divided into 3 grades in which the 1st and 2nd grade are treated by diuretics but the third grade is characterized by tense or marked ascites that requires large volume paracentesis (LVP) in addition to diuretics [8].

Salt restriction and diuretics (spironolactone and furosemide) are effective for ascites mobilization in $90 \%$ of 
the patients. Twenty percent will become diuretic resistant, while $10 \%$ of the patients will not respond from the start $[9,10]$.

\section{Main text}

Refractory ascites was identified by the International Ascites Club in a consensus conference in 1996, and it was defined as "ascites that cannot be mobilized, or early recurrence of ascites which cannot be satisfactorily prevented by medical therapy" [11].

\section{Modalities for tense ascites management}

Till now, the two common tools for management of patients with tense or refractory ascites are LVP and transjugular intrahepatic portosystemic shunt (TIPS) $[9,10]$.

LVP is an outpatient maneuver that is highly effective for the rapid relief of ascites and related symptoms [12]. It is effective in removing ascites in one single tap using suction pump to decrease the time to $1-2 \mathrm{~h}$ [13]. Compared to diuretics, it is more effective in maintaining ascites-free state, shorter hospital stay, fewer complications, and mobilization of edema [14].

In fact, LVP is a known maneuver since ancient Greeks but it lost the interest with advent of diuretics but it returned back for use in mid-1980s [15]. Beethoven underwent LVP twice (11 liters and 22 liters) but the second time was infected and leaked, which resulted in his death [16]. He was excited when he saw the ascitic fluid coming out, and he shouted that it reminded him of Prophet Moses who struck the rock with his staff and made the water gush forth $[17,18]$.

LVP may be an indirect measure of patient compliance as regards sodium intake. About $1300 \mathrm{mmol}$ sodium is removed by $10 \mathrm{~L} \mathrm{LVP}$. If the patient is consuming 88 $\mathrm{mmol} /$ day sodium without urinary sodium excretion and just $10 \mathrm{mmol} /$ day nonurinary sodium, $10 \mathrm{~L} \mathrm{LVP} \mathrm{will} \mathrm{re-}$ move 17 days of retained sodium in a patient with no sodium excretion. As a result, if the frequency of LVP $>2$ times/month, this means the patient is non-compliant with salt restriction $[9,19]$.

LVP is a safe maneuver, and the absolute contraindication is clinically evident fibrinolysis or clinically evident disseminated intravascular coagulation [20]. Pregnancy, severe bowel distension, and previous abdominal surgery are relative contraindication for non-ultrasound-guided (blind) paracentesis [21].

TIPS is an artificial bypass in which a shunt connects the portal vein to the hepatic vein through the liver. It was used in the past mainly for the treatment of variceal bleeding. Now, it is used for treatment of refractory ascites and hepatic hydrothorax [22]. Since the venous return increases with TIPS, the effective blood volume and the renal perfusion will improve with subsequent natriuresis. Hence, there is decreased rate of ascites formation or recurrence but unfortunately, the incidence of hepatic encephalopathy increases [23]. It was found that the nutritional status and quality of life improve markedly with TIPS [9].

Which is the better, LVP or TIPs? It is a continuous debate but generally, we should begin with LVP first but if the patient needs $>3$ sessions per months, we should assess for TIPS [10].

\section{Paracentesis-induced circulatory dysfunction:}

Paracentesis-induced circulatory dysfunction (PICD) is a serious complication of performing LVP without a plasma expander. It is defined as $50 \%$ increase in the plasma renin activity (PRA) over the baseline on the sixth day after treatment, up to a value $>4 \mathrm{ng} / \mathrm{mL}$ per hour [24].

Without the use of plasma expander, the following hemodynamics were recorded. Immediately after paracentesis, there is decreased abdominal pressure and increased venous return with suppression of the reninangiotensin-sympathetic nervous systems [25]. Unfortunately, opposite changes occur after $12 \mathrm{~h}$ with higher levels compared to before LVP [26]. In such case, the incidence of PICD was 75\% [27], and it may persist for months [28].

PICD is an asymptomatic condition but it is associated with serious effects as rapid re-accumulation of ascites, dilutional hyponatremia, increased incidence of hepatorenal syndrome, and short survival $[29,30]$. These consequences are noted if LVP is more than $5 \mathrm{~L}$ [27]. The development of PICD is not related to the paracentesis flow rate [31] unlike older studies [32]. Recently, $\beta$ blockers were accused as a risk factor for PICD. Sersté et al. [33] performed a self-control cross-over study. Ten patients with cirrhosis and refractory ascites treated with $\beta$ blockers were selected. When patients were given $\beta$ blockers, the prevalence of PICD was $80 \%$. After the withdrawal of $\beta$ blockers, the prevalence of PICD dropped to $10 \%$. Therefore, the authors concluded that the use of $\beta$ blockers may be associated with a high risk of PICD in patients with cirrhosis and refractory ascites.

\section{PICD prevention}

PICD can be prevented by multiple measures as albumin infusion, synthetic colloids, extracorporeal ultrafiltration and reinfusion, vasoconstrictors (midodrine, terlipressin, and noradrenaline), and recently low-dose albumin (Fig. 1).

All the studies compared a test drug to the standard of care (standard dose albumin infusion) but our study [29] was the first head-to-head multiple drug comparison.

Synthetic colloids showed contradictory results. Gines et al. [28] did not find dextran 70 useful. The same result was reported by El-Ashry et al. [34] and Nasr et al. [35]. Other studies found dextran 40 [36] and 3.5\% 


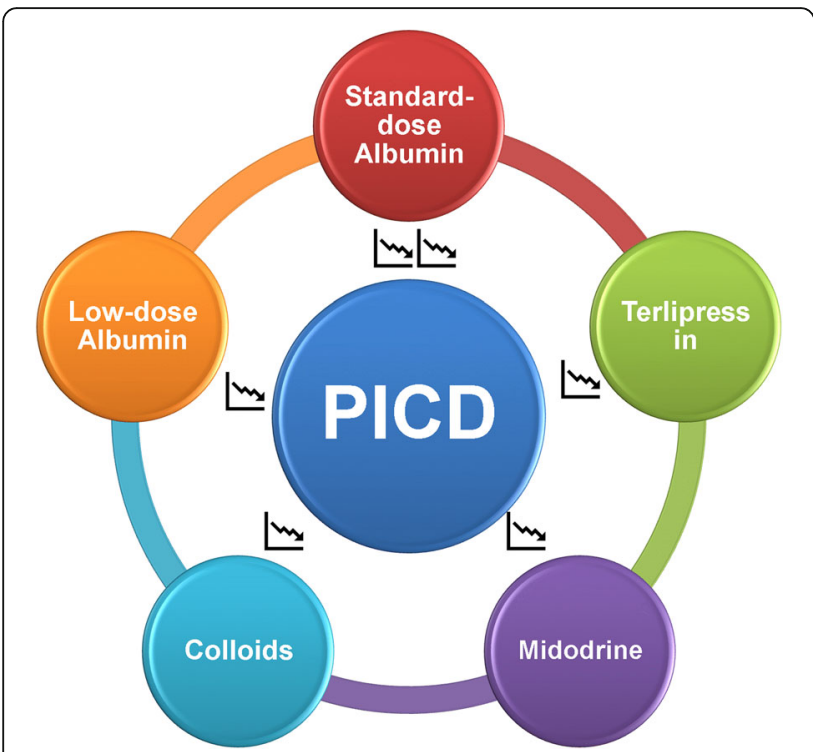

Fig. 1 Drugs used for the prevention of the paracentesis-induced circulatory dysfunction

polygeline $\left(\right.$ Haemaccel $\left.^{\circ}\right)$ [37] were also ineffective drugs. Recently, hydroxy-ethyl starch (HES 6\%) was found to be effective $(6-8 \mathrm{~g} / \mathrm{L})[29,38]$. Christidis et al. [39] found that HES could increase the portal pressure as it filled the Kupffer cells (lysosomal storage), and this would increase the risk of variceal bleeding.

Terlipressin is a splanchnic vasoconstrictor. It was studied for PICD prevention [29, 40-42]. Moreau et al. [40] evaluated 20 patients with tense ascites, 10 received terlipressin (total $3 \mathrm{mg} ; 1 \mathrm{~g}$ IV before, $8 \mathrm{~h}$, and $16 \mathrm{~h}$ after paracentesis) and the other 10 patients received albumin replacement $(8 \mathrm{~g} / \mathrm{L}$ ascites removed; $50 \%$ infused within $2 \mathrm{~h}$ after paracentesis and $50 \%$ after $6 \mathrm{~h}$ ). In each group, 3 patients developed PICD. There was significant weight reduction and no renal impairment development in both groups. Singh et al. [41] assigned 40 patients with tense ascites into 2 groups as Moreau et al. [40]. In each group, 2 patients developed PICD. There was significant weight reduction, but in each group, one patient developed renal impairment [41]. Lata et al. [42] studied 49 patient but he used different doses. Twenty-four received terlipressin ( $1 \mathrm{mg}$ every $4 \mathrm{~h}$ for $48 \mathrm{~h}$; the first dose given immediately after paracentesis), and the other twenty five received albumin replacement $(8 \mathrm{~g} / \mathrm{L}$ ascites removed; $50 \%$ infused with $2 \mathrm{~h}$ after paracentesis and $50 \%$ after $6 \mathrm{~h}$ ). The results in both treatment procedures suggested a similar efficacy for PICD prevention. In both groups, on the first 3 days, there was a tendency to improve hemodynamics reflected by the renin-angiotensin-aldosterone system activity. In the terlipressin group, this tendency approached statistically significant levels. All these studies found that terlipressin may be used as a measure for PICD prevention [29, 40-42].

Noradrenaline was assessed only in one study by Singh et al. [43] with promising results but no further studies.

Midodrine is an $\alpha 1$-agonist that increases the systemic and splanchnic blood pressure, circulating blood volume, and renal perfusion [44]. Midodrine is beneficial in hypotensive cirrhotic patients with refractory ascites [45].

Studies were contradictory as regards midodrine as a preventive measure for PICD [24, 29, 46]. Singh et al. [46] randomized 20 patients to receive midodrine (titrated dosage $5-10 \mathrm{mg} / 8 \mathrm{~h}$ to maintain a mean arterial pressure $10 \mathrm{mmHg}$ above baseline for $72 \mathrm{~h}$ ) and the other 20 patients to receive albumin $(8 \mathrm{~g} / \mathrm{L}$ ascitic fluid removed). No patient developed PICD in the midodrine group versus 2 in the albumin group. In contrast, in a study of 24 patients, Appenrodt et al. [24] randomized 11 patients to receive midodrine $(12.5 \mathrm{mg}$ every $8 \mathrm{~h}$ for 2 days) and the other 13 patients to receive albumin ( 8 $\mathrm{g} / \mathrm{L}$ ascitic fluid removed). In the midodrine group, one patient developed HRS precipitated by pneumonia, and he was excluded as he received terlipressin as treatment and eventually died. Six patients out of 10 (60\%) developed PICD in the midodrine versus 4 patients out of 9 (31\%) in the albumin group. There was marked increase in the plasma renin in the midodrine group. The authors did not recommend utilization of midodrine for the prevention of PICD. Notably, they gave fixed dose of midodrine for relatively shorter period, the patients did not stop diuretics, and finally, they did not exclude the diabetic patients. Hamdy et al. [47] found that patients in the midodrine arm had more incidence of renal impairment and PICD. Seven patients died in the midodrine arm in contrast to none in the albumin group.

Being much cheaper than albumin and terlipressin and much easier to administer, midodrine may be worth more trials to assess its use instead of albumin.

Albumin infusion is the approved standard-of-care measure for PICD prevention [48, 49]. Gines et al. [27] found that albumin infusion decreased the incidence of PICD from 80 to $15-20 \%$. A study by Tan et al. [50] had the same conclusion.

On one hand, there is some controversy regarding albumin infusion as being very expensive, causing inhibition of the endogenous albumin synthesis and increasing its degradation, $[51,52]$. On the other hand, albumin has many beneficial functions that reinforce its use apart from being plasma-expanding drug. Albumin detoxifies harmful reactive oxygen, stabilizes the endothelium, prevents platelets aggregation, and can modulate the immune and inflammatory responses [53].

In 2012, a meta-analysis conducted by Bernardi et al. [54] found that albumin infusion caused 60\% decrease of PICD development. Furthermore, albumin infusion 
decreased the hyponatremia and mortality. In 2017, Kütting et al. [55] conducted another meta-analysis with contradictory results. Kütting et al. found that albumin infusion decreased the incidence of hyponatremia and PICD development in patients without hepatocellular carcinoma. Albumin infusion in this meta-analysis unfortunately did not decrease mortality. Even in patients with hepatocellular carcinoma, the survival did not increase with albumin infusion. Their final conclusion was against albumin infusion.

The albumin dose is $6-8 \mathrm{~g}$ per liter of ascitic fluid removed $[48,49,56]$. It can be given once the session completed [57] or giving half the dose immediately after the paracentesis and the other half $6 \mathrm{~h}$ later $[28,29,58]$.

Low-dose albumin infusion was studied by Alessandria et al. (4 g/L ascites removed) [59] and Alsebaey et al. (2 $\mathrm{g} / \mathrm{L}$ ascites removed) [29]. Thirty-five patients were randomized by Alessandria et al. [59] for half dose albumin $(4 \mathrm{~g} / \mathrm{L}$ ascites) and 35 patients to full dose albumin $(8 \mathrm{~g} /$ $\mathrm{L}$ ascites removed). PICD developed in 5 patients (14\%) in the half dose albumin group and in 7 patients (20\%) in the full dose albumin group with no significant difference. They concluded that albumin in half dose is equivalent to full dose albumin in prevention of PICD. Alsebaey et al. [29] found same finding despite lower doses.

Our study [29] was the first head-to-head comparison of different drugs for PICD prevention. It included 125 patients randomized to 5 equal groups. In the albumin group, the dose was $6 \mathrm{~g} / \mathrm{L}$. In the low-dose albumin group, the dose was $2 \mathrm{~g} / \mathrm{L}$. Hydroxyethyl starch (HES $130 / 0.4$ ) was given as $8 \mathrm{~g} / \mathrm{L}$. Terlipressin dose was $1 \mathrm{mg}$ $\mathrm{IV}$ at the onset then every $8 \mathrm{~h}$ for a maximum of $3 \mathrm{~g}$ per day. Midodrine was administered orally for 3 days (5-10 mg 8 hourly to maintain the MAP at $10 \mathrm{mmHg}>$ the baseline). All groups were statistically comparable as regards the age, sex, the etiology of the liver disease, and the Child-Pugh score. Most patients had hepatitis Crelated liver cirrhosis. The average volume of ascitic fluid removed was $13 \pm 0.14 \mathrm{~L}$. PICD occurred in two patients in both terlipressin and HES 130/0.4 groups. In each albumin group, three patients developed PICD. Five patients in the midodrine group developed PICD. Comparing all groups showed no significant difference. We concluded that low-dose albumin, terlipressin, and HES 130/0.4 were good alternatives to the standard-ofcare albumin dose.

We published another new study [60] focusing on the use of low-dose albumin $2 \mathrm{~g} / \mathrm{L}$ ascitic fluid removed $(n=$ 85). The incidence of PICD development was comparable to the standard dose albumin. In the same study, we did again comparison of the new number of the lowdose albumin to the other old arms, namely, terlipressin, midodrine, HES 130/0.4, and standard dose albumin. All the groups again were the same for PICD development.

The recent European Association for the Study of the Liver guidelines [56], however, still recommend albumin $(8 \mathrm{~g} / \mathrm{L}$ ascites removed) and did not recommend other alternatives.

\section{Conclusions}

PICD is a harmful complication of large volume paracentesis that should be prevented by plasma expanders. Albumin infusion in the standard dose is the standard drug till now but other alternatives are promising.

\section{Abbreviations}

LVP: Large volume paracentesis; TIPS: Transjugular intrahepatic portosystemic shunt; PICD: Paracentesis induced circulatory dysfunction

\section{Acknowledgements}

The authors thank all the members of Hepatology and Gastroenterology Department, National Liver Institute, Egypt.

\section{Authors' contributions}

AA put the plan of the review article, searched the PubMed and google scholar for relevant studies, summarized them, and wrote the manuscript. ER and IW revised the manuscript. All authors have read and approved the final manuscript.

\section{Funding \\ None}

Availability of data and materials

NA

\section{Ethics approval and consent to participate}

NA.

\section{Consent for publication}

NA

\section{Competing interests}

$A A$ and ER declare that they have no conflict of interest. IW: Imam Waked: investigator and/or speaker for Abbvie, Gilead Sciences, Janssen, Marcyrl, Onxio, Pharco.

Received: 27 August 2019 Accepted: 28 July 2020

Published online: 05 August 2020

\footnotetext{
References

1. Bryan CP (1931) The papyrus Ebers. D. Appleton, New York, pp 134-135

2. Ghaliounghui P (1987) The Ebers Papyrus. Academy of Scientific Research and Technology, Cairo

3. Dawson AD (1960) Historical notes on ascites. Gastroenterology 39:790-791

4. Richert A, Raines D, Lopez FA (2009) New onset ascites secondary to cirrhosis. J La State Med Soc 161(1):9-13 quiz 13, 54

5. Lee JM, Han K-H, Ahn SH (2009) Ascites and spontaneous bacterial peritonitis: An Asian perspective. J Gastroenterol Hepatol 24(9):1494-1503

6. Rochling FA, Zetterman RK (2009) Management of ascites. Drugs 69(13): 1739-1760

7. Møller S, Henriksen JH, Bendtsen F (2009) Ascites: pathogenesis and therapeutic principles. Scand J Gastroenterol 44(8):902-911

8. Zullo A, Hassan C, Lorenzetti R (2011) Rifaximin therapy in minimal hepatic encephalopathy cirrhotics. Am J Gastroenterol 106(11):2041 author reply 2041-2

9. Senousy BE, Draganov PV (2009) Evaluation and management of patients with refractory ascites. World J Gastroenterol 15(1):67-80

10. Singhal S, Baikati KK, Jabbour S II (2012) Anand, Management of refractory ascites. Am J Ther 19(2):121-132
} 
11. Arroyo V, Ginès P, Gerbes AL, Dudley FJ, Gentilini P, Laffi G, Reynolds TB, Ring-Larsen H, Schölmerich J (1996) Definition and diagnostic criteria of refractory ascites and hepatorenal syndrome in cirrhosis. Hepatology (Baltimore, Md) 23(1):164-176

12. Grabau CM, Crago SF, Hoff LK, Simon JA, Melton CA, Ott BJ, Kamath PS (2004) Performance standards for therapeutic abdominal paracentesis. Hepatology (Baltimore, Md) 40(2):484-488

13. Kuiper JJ, De Man RA, Van Buuren HR (2007) Review article: management of ascites and associated complications in patients with cirrhosis. Aliment Pharmacol Ther 26:183-193

14. Peltekian KM, Wong F, Liu PP, Logan AG, Sherman M, Blendis LM (1997) Cardiovascular, renal, and neurohumoral responses to single large-volume paracentesis in patients with cirrhosis and diuretic-resistant ascites. Am J Gastroenterol 92(3):394-399

15. Cardenas A, Arroyo V (2005) Refractory ascites. Dig Dis 23(1):30-38

16. Kubba AK, Young M (1996) Ludwig van Beethoven: a medical biography. Lancet 347(8995):167-170

17. Reuben A (2002) Out came copious water. Hepatology (Baltimore, Md) 36(1):261-264

18. Adams PC (1987) Historical hepatology: Ludwig van Beethoven. J Gastroenterol Hepatol 2(4):375-379

19. Schouten J, Michielsen PP (2007) Treatment of cirrhotic ascites. Acta Gastroenterol Belg 70(2):217-222

20. Runyon BA (2009) Management of adult patients with ascites due to cirrhosis: an update. Hepatology (Baltimore, Md) 49(6):2087-2107

21. McGibbon A, Chen Gl, Peltekian KM, van Zanten SV (2007) An evidencebased manual for abdominal paracentesis. Dig Dis Sci 52(12):3307-3315

22. Boyer TD (2003) Transjugular intrahepatic portosystemic shunt: current status. Gastroenterology 124(6):1700-1710

23. W. Hou, A.J. Sanyal, Ascites: diagnosis and management, Med Clin North Am 93(4) (2009) 801-817, vii.

24. Appenrodt B, Wolf A, Grünhage F, Trebicka J, Schepke M, Rabe C, Lammert F, Sauerbruch T, Heller J (2008) Prevention of paracentesis-induced circulatory dysfunction: midodrine vs albumin. A randomized pilot study. Liver Int 28(7):1019-1025

25. Pozzi M, Redaelli E, Ratti L, Poli G, Guidi C, Milanese M, Calchera I, Mancia G (2005) Time-course of diastolic dysfunction in different stages of chronic HCV related liver diseases. Minerva Gastroenterol Dietol 51(2):179-186

26. Ruiz-del-Arbol L, Monescillo A, Arocena C, Valer P, Ginès P, Moreira V, María Milicua J, Jiménez W, Arroyo V (2005) Circulatory function and hepatorenal syndrome in cirrhosis. Hepatology (Baltimore, Md) 42(2):439-447

27. Gines $P$, Tito L, Arroyo V, Planas R, Panes J, Viver J, Torres M, Humbert P, Rimola A, Llach J et al (1988) Randomized comparative study of therapeutic paracentesis with and without intravenous albumin in cirrhosis. Gastroenterology 94(6):1493-1502

28. Gines A, Fernandez-Esparrach G, Monescillo A, Vila C, Domenech E, Abecasis R, Angeli P, Ruiz-Del-Arbol L, Planas R, Sola R, Gines P, Terg R, Inglada L, Vaque P, Salerno F, Vargas V, Clemente G, Quer JC, Jimenez W, Arroyo V, Rodes J (1996) Randomized trial comparing albumin, dextran 70, and polygeline in cirrhotic patients with ascites treated by paracentesis. Gastroenterology 111(4):1002-1010

29. Alsebaey A, Abdel-Razek W, Bassuni A, Rewisha E, Khalil M, Waked I (2013) Prevention of paracentesis-induced circulatory dysfunction: could we use other albumin alternatives? Egyptian Liver Journal 3(4):118-125

30. Salerno F, Guevara M, Bernardi M, Moreau R, Wong F, Angeli P, Garcia-Tsao G, Lee SS (2010) Refractory ascites: pathogenesis, definition and therapy of a severe complication in patients with cirrhosis. Liver Int 30(7):937-947

31. Elsabaawy MM, Abdelhamid SR, Alsebaey A, Abdelsamee E, Obada MA, Salman TA, Rewisha E (2015) The impact of paracentesis flow rate in patients with liver cirrhosis on the development of paracentesis induced circulatory dysfunction. Clin Mol Hepatol 21(4):365-371

32. Coll S, Vila MC, Molina L, Gimenez MD, Guarner C, Sola R (2004) Mechanisms of early decrease in systemic vascular resistance after total paracentesis: influence of flow rate of ascites extraction. Eur J Gastroenterol Hepatol 16(3):347-353

33. Sersté T, Francoz C, Durand F, Rautou P-E, Melot C, Valla D, Moreau R, Lebrec D Beta-blockers cause paracentesis-induced circulatory dysfunction in patients with cirrhosis and refractory ascites: a cross-over study. J Hepatol 55(4):794-799

34. El-Ashry N, El-Damarawy M, Salem M, Mogawer S (2007) Large volume abdominal paracentesis effect on some humoral factors and cardiac performance in patients with liver cirrhosis and tense ascities. J Egypt Soc Parasitol 37(2):571-584

35. Nasr G, Hassan A, Ahmed S, Serwah A (2010) Predictors of large volume paracantesis induced circulatory dysfunction in patients with massive hepatic ascites. J Cardiovasc Dis Res 1(3):136-144

36. Garcia-Compean D, Blanc P, Larrey D, Daures JP, Hirtz J, Mendoza E, Maldonado $H$, Michel $H$ (2002) Treatment of cirrhotic tense ascites with Dextran-40 versus albumin associated with large volume paracentesis: a randomized controlled trial. Ann Hepatol 1(1):29-35

37. Moreau R, Valla DC, Durand-Zaleski I, Bronowicki JP, Durand F, Chaput JC, Dadamessi I, Silvain C, Bonny C, Oberti F, Gournay J, Lebrec D, Grouin JM, Guemas E, Golly D, Padrazzi B, Tellier Z (2006) Comparison of outcome in patients with cirrhosis and ascites following treatment with albumin or a synthetic colloid: a randomised controlled pilot trail. Liver Int 26(1):46-54

38. Abdel-Khalek EE, Arif SE (2010) Randomized trial comparing human albumin and hydroxyethyl starch $6 \%$ as plasma expanders for treatment of patients with liver cirrhosis and tense ascites following large volume paracentesis. Arab Journal of Gastroenterology 11(1):24-29

39. Christidis C, Mal F, Ramos J, Senejoux A, Callard P, Navarro R, Trinchet JC, Larrey D, Beaugrand M, Guettier C (2001) Worsening of hepatic dysfunction as a consequence of repeated hydroxyethylstarch infusions. J Hepatol 35(6): 726-732

40. Moreau R, Asselah T, Condat B, de Kerguenec C, Pessione F, Bernard B, Poynard T, Binn M, Grangé JD, Valla D, Lebrec D (2002) Comparison of the effect of terlipressin and albumin on arterial blood volume in patients with cirrhosis and tense ascites treated by paracentesis: a randomised pilot study. Gut 50(1):90-94

41. Singh V, Kumar R, Nain CK, Singh B, Sharma AK (2006) Terlipressin versus albumin in paracentesis-induced circulatory dysfunction in cirrhosis: a randomized study. J Gastroenterol Hepatol 21(1):303-307

42. Lata J, Marecek Z, Fejfar T, Zdenek P, Bruha R, Safka V, Hulek P, Hejda V, Dolina J, Stehlik J, Tozzi I (2007) The efficacy of terlipressin in comparison with albumin in the prevention of circulatory changes after the paracentesis of tense ascites--a randomized multicentric study. Hepatogastroenterology 54(79):1930-1933

43. Singh V, Kumar B, Nain CK, Singh B, Sharma N, Bhalla A, Sharma AK (2006) Noradrenaline and albumin in paracentesis-induced circulatory dysfunction in cirrhosis: a randomized pilot study. J Intern Med 260(1):62-68

44. Tandon P, Tsuyuki RT, Mitchell L, Hoskinson M, Ma MM, Wong WW, Mason AL, Gutfreund K, Bain VG (2009) The effect of 1 month of therapy with midodrine, octreotide-LAR and albumin in refractory ascites: a pilot study. Liver Int 29(2):169-174

45. Sourianarayanane A, Barnes DS, McCullough AJ (2011) Beneficial Effect of Midodrine in Hypotensive Cirrhotic Patients with Refractory Ascites. Gastroenterol Hepatol 7(2):132-134

46. Singh V, Dheerendra PC, Singh B, Nain CK, Chawla D, Sharma N, Bhalla A, Mahi SK (2008) Midodrine versus albumin in the prevention of paracentesisinduced circulatory dysfunction in cirrhotics: a randomized pilot study. Am J Gastroenterol 103(6):1399-1405

47. Hamdy H, ElBaz AA, Hassan A, Hassanin O (2014) Comparison of midodrine and albumin in the prevention of paracentesis-induced circulatory dysfunction in cirrhotic patients: a randomized pilot study. J Clin Gastroenterol 48(2):184-188

48. European Association for the Study of the Liver EASL clinical practice guidelines on the management of ascites, spontaneous bacterial peritonitis, and hepatorenal syndrome in cirrhosis. J Hepatol 53(3):397-417

49. Runyon BA (2013) Introduction to the revised American Association for the Study of Liver Diseases Practice Guideline management of adult patients with ascites due to cirrhosis 2012. Hepatology (Baltimore, Md) 57(4):1651-1653

50. Tan HK, James PD, Wong F (2016) Albumin may prevent the morbidity of paracentesis-induced circulatory dysfunction in cirrhosis and refractory ascites: a pilot study. Dig Dis Sci 61(10):3084-3092

51. M.A. Rothschild, M. Oratz, C. Evans, S.S. Schreiber, Alterations in albumin metabolism after serum and albumin infusions, J Clin Invest 43 (1964) 1874-1880.

52. Wilkinson P, Sherlock S (1962) The effect of repeated albumin infusions in patients with cirrhosis. Lancet 2(7266):1125-1129

53. Caraceni $P$, Angeli $P$, Prati $D$, Bernardi $M$, Alessandria $C$, Riggio $O$, Salerno $F$, Liumbruno GM, Bennardello F, Piccoli P, Velati C, Berti P, Facco G, Fiorin F 
(2016) AISF-SIMTI Position Paper: The appropriate use of albumin in patients with liver cirrhosis. Dig Liver Dis 48(1):4-15

54. Bernardi M, Caraceni P, Navickis RJ, Wilkes MM (2012) Albumin infusion in patients undergoing large-volume paracentesis: a meta-analysis of randomized trials. Hepatology (Baltimore, Md) 55(4):1172-1181

55. Kutting F, Schubert J, Franklin J, Bowe A, Hoffmann V, Demir M, Pelc A, Nierhoff D, Tox U, Steffen HM (2017) Insufficient evidence of benefit regarding mortality due to albumin substitution in HCC-free cirrhotic patients undergoing large volume paracentesis. J Gastroenterol Hepatol 32(2):327-338

56. Angeli P, Bernardi M, Villanueva C, Francoz C, Mookerjee RP, Trebicka J, Krag A, Laleman W, Gines P (2018) EASL Clinical Practice Guidelines for the management of patients with decompensated cirrhosis. J Hepatol 69(2): 406-460

57. K.P. Moore, G.P. Aithal, Guidelines on the management of ascites in cirrhosis, Gut 55 Suppl 6 (2006) vi1-v12.

58. Planas R, Gines P, Arroyo V, Llach J, Panes J, Vargas V, Salmeron JM, Gines A, Toledo C, Rimola A et al (1990) Dextran-70 versus albumin as plasma expanders in cirrhotic patients with tense ascites treated with total paracentesis. Results of a randomized study. Gastroenterology 99(6):1736-1744

59. Alessandria C, Elia C, Mezzabotta L, Risso A, Andrealli A, Spandre M, Morgando A, Marzano A, Rizzetto M (2011) Prevention of paracentesisinduced circulatory dysfunction in cirrhosis: Standard vs half albumin doses. A prospective, randomized, unblinded pilot study. Dig Liver Dis 43(11):881-886

60. Alsebaey A, Rewisha E, Waked I (2020) High efficacy of low-dose albumin infusion in the prevention of paracentesis-induced circulatory dysfunction. Egyptian Liver Journal 10(1):9

\section{Publisher's Note}

Springer Nature remains neutral with regard to jurisdictional claims in published maps and institutional affiliations.

\section{Submit your manuscript to a SpringerOpen ${ }^{\circ}$ journal and benefit from:}

- Convenient online submission

- Rigorous peer review

- Open access: articles freely available online

- High visibility within the field

- Retaining the copyright to your article

Submit your next manuscript at $\boldsymbol{\nabla}$ springeropen.com 